\title{
The Decrasing Trend of Precipitation Observed at Watesheds in Padang for The Period 1975-2013
}

\author{
Ratna Wilis ${ }^{1}$ and Sugeng Nugroho ${ }^{2}$ \\ ${ }^{1}$ Geography Department, Universitas Negeri Padang \\ ${ }^{2}$ BMKG West Sumatra \\ Email: ratna_geounp@yahoo.com
}

\begin{abstract}
One of the consequences of the ongoing climate change is the increasing likelihood of extreme precipitation frequency in the future, which causes the declining trend of total precipitation that affects water debits in the watersheds and brings difficulties to a city like Padang that is situated near the watersheds. In order to elaborate on this, a number of extreme precipitation indices recommended by ETCCDMI was utilized to assess the extreme precipitation condition for the period 1975-2013. These indices were calculated based on the rain-gauge stations along the watersheds in and around Padang. Before processing the data, a series of homogeneity test were undertaken to make sure the data were comparable. The results showed that there was a significant declining trend on the total annual precipitation (PRCPTOT), an increasing trend of the number of days without rain (R0) and a decreasing frequency of the number of days with precipitation of more than 50 $\mathrm{mm}$ in the Batang Kuranji Watershed. The results suggested that atmospheric circulations, such as El Nino and positive Dipole Mode, have played their role on the trend as a result of their intensified frequency due to global warming.
\end{abstract}

Keywords: Extremes Climate Index, Declining Trend of Precipitation, Global Atmospheric Circulations

\section{Introduction}

Padang, the capital city of West Sumatra Province, has six watersheds in and around the city, namely Batang Kandis, Batang Arau, Batang Kuranji, Batang Air Dingin, Batang Timbulan and Batang Anak Pisang. All together, these watersheds cover a total area of 69,496 hectares. Geologically, Padang is situated in an Alluvial area formed by three main river systems, which are Batang Arau, Batang Kuranji and Batang Air Dingin, with the catchment areas are originated from Mount Bolak, Mount Lantik and Mount Bongsu (Putra, 2012).

Watershed management becomes a central issue, as its function is to maintain the watershed hydrologic balance in order to contribute to economic, ecological and societal benefits. The ongoing global warming phenomenon that leads to a changing climate is believed to perturb the watershed hydrologic balance, which in turns will disrupt the water resource. Global warming is a phenomenon in which the present of greenhouse gases in the atmosphere prevent the radiation energy from the sun to escape from the earth's surface, resulting an increasing trend of global surface temperatures. Even though the increase is relatively small, this trend has a long-term chain effect to the meteorological or climatological parameters, particularly to the hydrological cycle. To evaluate how climate change might affect water availability, it is therefore important to develop a study on the water sources by using a holistic approach, both in physical and societal aspects.

A water source in the watersheds is regarded as one of the renewable natural resources, as its total amount is kept relatively unchanged by the means of hydrologic cycle. However, the present of climate 
change might influence the main component in this cycle, which is precipitation. As the main source of water for a watershed, precipitation may actually play as a 'double-headed sword'; it causes floods and landslides when it is excessively occurring, whereas prolonged droughts come as a result of the lack of precipitation. The global warming triggered climate change is often featured by the occurrence of extreme weather events, such as heavy precipitation in one time and a period of long dry condition in another time. These extremes obviously bring disadvantages for people who live nearby a watershed.

One of the most significant consequences of global warming is the intensification in magnitude and frequency of extreme precipitation, which indirectly influences the increase of air humidity, as well as the amplification of thunderstorm chances and the affected-areas. In a number of global warming scenarios, climate models are generally in agreement for predicting the possibility of intensified extreme precipitation in a larger scale (Joshi and Rajeevan, 2006). Studies on extreme climate have been done in a number of areas, such as central and southern Asia (Klein Tang, 2006), Middle East (Zhang, 2005), and South Asian countries (Sheikh et al, 2005). A results studied found a obvious incremental trend of precipitation in the western part of Northwest China while the opposite situation happened in the northern part. Still on their findings, it was discovered that on a nation-wide scale the number of rainy days is in a negative trend, with the counted precipitation amount for these days is particularly bigger than $10 \mathrm{~mm}, 50 \mathrm{~mm}$, or even $100 \mathrm{~mm}$ (Zai et al, 1999). The other studied extreme precipitation events in India for the period 1910-2000 and have found that generally the phenomena have increased in frequency, especially in the areas around north-western Himalaya near the Kashmir border, Deccan Valley and the southern side of the subcontinent (Roy et al, 2004). They study also revealed that a contrast situation has occurred in the Gangetic lowland and parts of Uttaranchal. In an earlier study, have detected an increasing precipitation trend from the period 1817-1984 in the west coast and south west of India while the decreasing trend was measured in the east of Madhya Pradesh (Rupa et al., 1992).

A similar results studied for Australia have reached to a conclusion that a significant declining trend on the frequency and intensity of extreme precipitation has been experienced by the western part of the continent, whereas the eastern side was in a contrast situation (Haylock and Neville, 2000). Another research activity conducted in Australia added that most of the country has undergone heavy precipitations around the year, except the western part that has seen a decrease both in the number of days and the frequency (Suppiah and Hennessy, 1998). From a local perspective, a study on the extreme precipitation trend in Padang for the period 1970-2008 has concluded that based on a number of extreme precipitation trend indices, the annual total amount of precipitation in Padang has been decreasing. The results also indicated that the amount of precipitation in Padang was accumulated in a particular time within the observation period, leading to an incremental tendency of the precipitation intensity in the city. Besides the evaluation purposes, these indices can also be utilized to investigate the projection of extreme precipitation trend in Padang for the future. This projection is simulated with the consideration of the variability of atmospheric circulations on a wider scale (regional or global) (Nugroho et al, 2009).

It has been suggested that climate change might affect the water debit in rivers, with an inclination toward a lower water level due to the diminished precipitation in the catchment areas. Consequently, a number of facilities and activities related to the changes in water debit, such as irrigations, hydropower plants, fishery farmings and tourism, might as well be affected. It has become evident that water in some watersheds in and around Padang has been reduced, which lead to some difficulties with regard to generating electricity from the power plant and to irrigating the farmlands in this area. The main aim of this research was to analyze the trend and variability of extreme precipitation in watersheds around Padang. The research covered a period of the last 30-40 years, depends on the data availability. The outcomes were expected to be useful to signal the current climate change, in order to better formulate adaptation and mitigation strategies, 
not only for the people and environment around the watersheds, but also for larger community that might directly or indirectly be affected by the decreasing precipitation trend in the watersheds.

\section{Methods}

The study was conducted at a number of rain-gauge stations that are located along the watersheds surround Padang. For Batang Kuranji Watershed, four gauging stations were taken as samples, which are Simpang Alai, Batu Busuk, Gunung Nago, and Tabing. Meanwhile, Batang Air Dingin Watershed and Batang Arau Watershed are each represented by one station: Gunung Sarik and Ladang Padi, respectively. Details and locations of these stations can further be studied from Figure 1 and Table 1. Four out of six stations, namely Gunung Sarik, Batu Busuk, Gunung Nago and Ladang Padi are all located in the upstream areas of the watersheds while Tabing and Simpang Alai are near the downstreams. There are actually three more stations in these watersheds: Komplek PU, Teluk Bayur and Bungus. These stations, however, were not considered in this study as the data are relatively short.

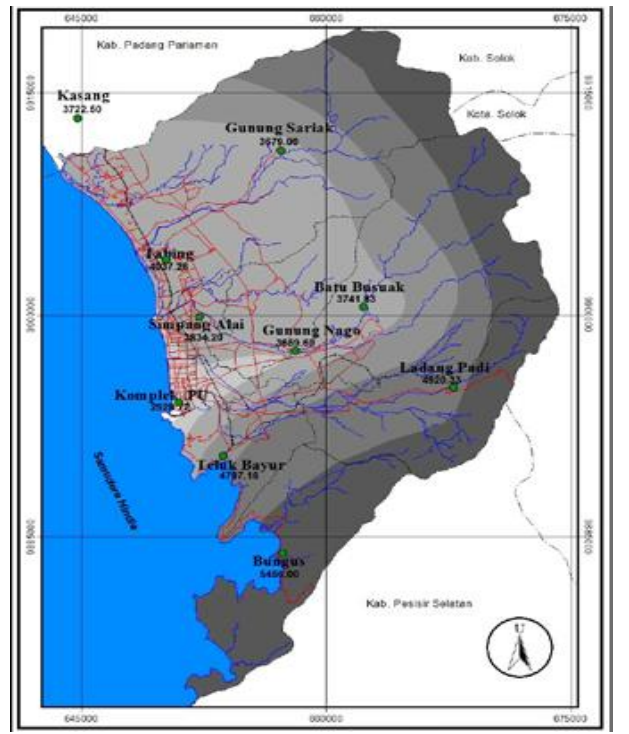

Figure 1. Rain-gauge stations in the area of study.

Table 1. Rain-gauge locations, covered period and data source

\begin{tabular}{|c|l|c|c|l|c|c|c|}
\hline \multirow{2}{*}{ No. } & \multirow{2}{*}{ Rain-gauge locations } & \multirow{2}{*}{ Lon. } & \multirow{2}{*}{ Lat. } & \multicolumn{2}{|c|}{ Watershed } & \multicolumn{3}{|c|}{ Deriod } & Source \\
\cline { 4 - 8 } & & & & & & \multicolumn{3}{|c|}{1975} & 2013 & PSDA \\
\hline 1 & Simpang Alai & 100.44 & -0.93 & Batang Kuranji & 1975 & 2013 & PSDA \\
\hline 2 & Batu Busuk & 100.45 & -0.90 & Batang Kuranji & 1980 & 2013 & PSDA \\
\hline 3 & Gunung Nago & 100.45 & -0.90 & Batang Kuranji & 1970 & 2012 & BMKG \\
\hline 4 & Tabing & 100.37 & -0.88 & Batang Kuranji & 1975 & 2013 & PSDA \\
\hline 5 & Gunung Sarik & 100.41 & -0.88 & Batang Air Dingin & 1975 & 2013 & PSDA \\
\hline 6 & Ladang Padi & 100.52 & -0.95 & Batang Arau & &
\end{tabular}

\section{Data processing}

\section{Precipitation data homogeneity}

There are a number of statistical methods can be employed to do data homogeneity test for precipitation dataseries. In this study, an R-language based software package 'RHtest_dlyPrcp' was in use. This package was developed by the Climate Research Division, a unit under Environment Canada. It is 
intended as a part of software package for detecting and monitoring extreme climate events with the capability of performing detection and adjustment to the suspected changepoints that might be found in the data series. In this package, there is a Quantile-Matching option that can be selected to perform data adjustment. The empirical distribution of all the segments that has de-trend basis will be matching between one and the others, which the adjustment values depend on the empirical frequency of each datum of the adjusted dataseries. More details on this package can be perused from etccdmi.pacificclimate.org (Wang and Feng, 2013).

\section{Extreme precipitation indices}

To determine the extreme precipitation indices, RClimDex, another R-language based software package developed by the same institution that provides the precipitation data homogeneity test, was chosen. The main focus of this package is to detect and monitor extreme climate events by optimizing daily data collected from meteorological/climatological stations (Zhang and Yang, 2014). This package and the manual can be found in cccma.seos.uvic.ca/ETCCDMI. In this package, there are actually 27 essential extreme indices that can be used. However, as this study was focusing on extreme precipitation events, only relevant indices that were used. These indices are annual total precipitation trend (PRCPTOT), maximum 1-day precipitation amount trend (RX1D), maximum consecutive 5-day precipitation amount trend (RX5D), maximum number of consecutive days with precipitation $<1 \mathrm{~mm}$ trend (CDD), maximum number of consecutive days with precipitation $\geq 1 \mathrm{~mm}$ trend (CWD), number of days with no precipitation trend (R0), number of days with precipitation at least $50 \mathrm{~mm}$ trend (R50) and number of days with precipitation more than $100 \mathrm{~mm}$ trend (R100). Table 2 has the summary of these indicies.

\section{Significance}

To determine the significance of the results from each index, Mann Kendal test was carried out by using the Makensen program. This program, a template that is operated under Microsoft Excel, is a statistic tool developed by the Finland Meteorological Institute in 2002, to be used to calculate annual trend variation (Timo et al., 2002).

Table 2. Selected extreme precipitation indices from the RClimDex software package

\begin{tabular}{|c|c|c|c|}
\hline ID & Indicator name & Definitions & Units \\
\hline PRCPTOT & $\begin{array}{l}\text { Annual total wet-day } \\
\text { precipitation }\end{array}$ & Annual total PRCP in wet days $(\mathrm{RR}>=1 \mathrm{~mm})$ & $\mathrm{mm}$ \\
\hline RX1D & $\begin{array}{l}\text { Max 1-day precipitation } \\
\text { amount }\end{array}$ & Monthly maximum 1-day precipitation & $\mathrm{mm}$ \\
\hline $\mathrm{Rx} 5 \mathrm{D}$ & $\begin{array}{l}\text { Max 5-day precipitation } \\
\text { amount }\end{array}$ & Monthly maximum consecutive 5-day precipitation & $\mathrm{mm}$ \\
\hline CDD & Consecutive dry days & Maximum number of consecutive days with $\mathrm{RR}<1 \mathrm{~mm}$ & Days \\
\hline CWD & Consecutive wet days & Maximum number of consecutive days with $\mathrm{RR}>=1 \mathrm{~mm}$ & Days \\
\hline R0 & $\begin{array}{l}\text { Number of days no } \\
\text { precipitation }\end{array}$ & Annual count of days when $\mathrm{PRCP}=0 \mathrm{~mm}$, (user defined threshold & Days \\
\hline $\mathrm{R} 50$ & Number of days above $50 \mathrm{~mm}$ & $\begin{array}{l}\text { Annual count of days when } \mathrm{PRCP}>=50 \mathrm{~mm} \text {, (user defined } \\
\text { threshold }\end{array}$ & Days \\
\hline R100 & $\begin{array}{l}\text { Number of days above } 100 \\
\mathrm{~mm}\end{array}$ & $\begin{array}{l}\text { Annual count of days when } \mathrm{PRCP}>=100 \mathrm{~mm} \text {, (user defined } \\
\text { threshold }\end{array}$ & Days \\
\hline
\end{tabular}




\section{Results and Discussion}

\section{Precipitation dataseries homogenity}

The precipitation dataseries homogeneity test has found that, of the six rain-gauge station used in this study, only data collected from Tabing that was homogeneous while the other five were found to be inhomogeneous so some data adjustment have to be undertaken. The homogeneous precipitation dataseries exerted by Tabing can be seen in Figure 2.

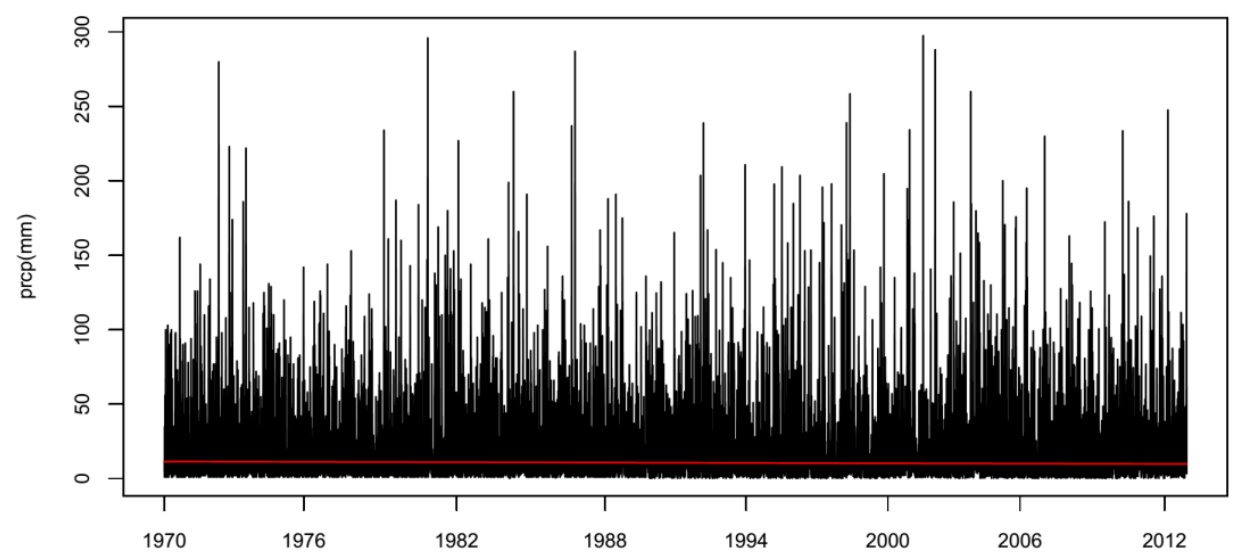

Figure 2. Precipitation dataseries plot for the rain-gauge station in Tabing.

One of the rain-gauge stations that has inhomogeneous data was Simpang Alai, in which the changepoint has shown that the data from 2007 and 2010 have to be adjusted due to inconsistency of homogeneity (Figure 3a). The QM adjustment was then done for the changepoint on 24 April 2008 (Figure 3b), and as a result the newly made dataseries from the adjustment can be seen in Figure $3 \mathrm{c}$. The same method was also applied for the other rain-gauge stations that have data inhomogeneity. It is however worth to mention that the QM adjustment was performed without taking into consideration the reasons of the inhomogeneity due to the fact that the metadata from the stations are not available.

\section{Extreme precipitation indices}

The results of extreme precipitation index trends and the significance test on the trends with a confident level of 5\% can examined in the following Table 3 and Table 4. As seen from Table 3, most of the rain-gauge stations show decreasing trends of annual precipitation, shown as negative values of PRCPTOT. It is found that only one station, which is Ladang Padi, that has a positive value. The highest negative value (75.7 mm/year) was calculated for Batu Busuk, followed by Simpang Alai, Gunung Nago, and the lowest value is for Tabing $(5.91 \mathrm{~mm} / \mathrm{year})$. All of these stations happened to be around the Batang Kuranji Watershed. A similar declining trend is also observed in Gunung Sarik as part of the Batang Air Dingin Watershed, with the precipitation is decreasing at a rate of $40.63 \mathrm{~mm} /$ year. In contrast, a positive trend indicating an increase of a long-term precipitation dataseries was calculated for Ladang Padi of the Batang Arau Watershed, with the increasing rate of $19.61 \mathrm{~mm} / \mathrm{year}$.

The results of significance test for PRCPTOT index trend showed that the trends were only significance for Batu Busuk and Simpang Alai (refer to Table 4), suggesting the decreasing trend of annual precipitation is significantly occurring in the Batang Kuranji Watershed. The results of significance test for PRCPTOT index trend showed that the trends were only significance for Batu Busuk and Simpang Alai (refer to Table 4), suggesting the decreasing trend of annual precipitation is significantly occurring in the Batang Kuranji Watershed. 


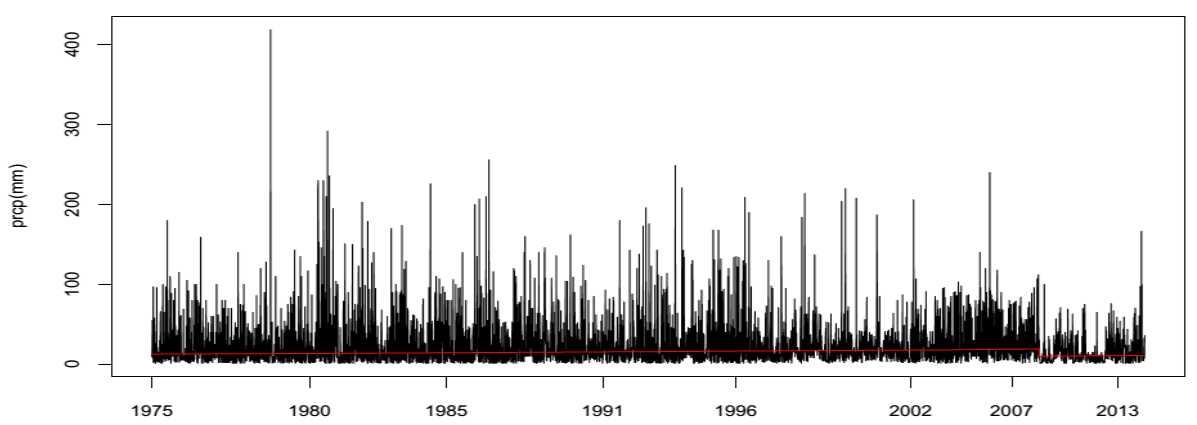

Figure 3a. The inhomogeneous precipitation dataseries plot for Simpang Alai.

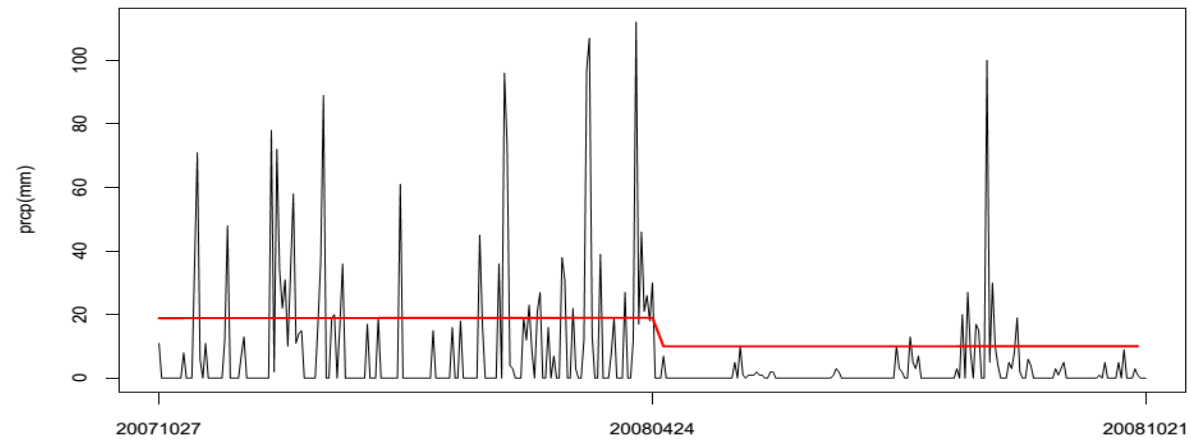

Figure 3b. The changepoint precipitation dataseries plot for Simpang Alai on 24 April 2008.

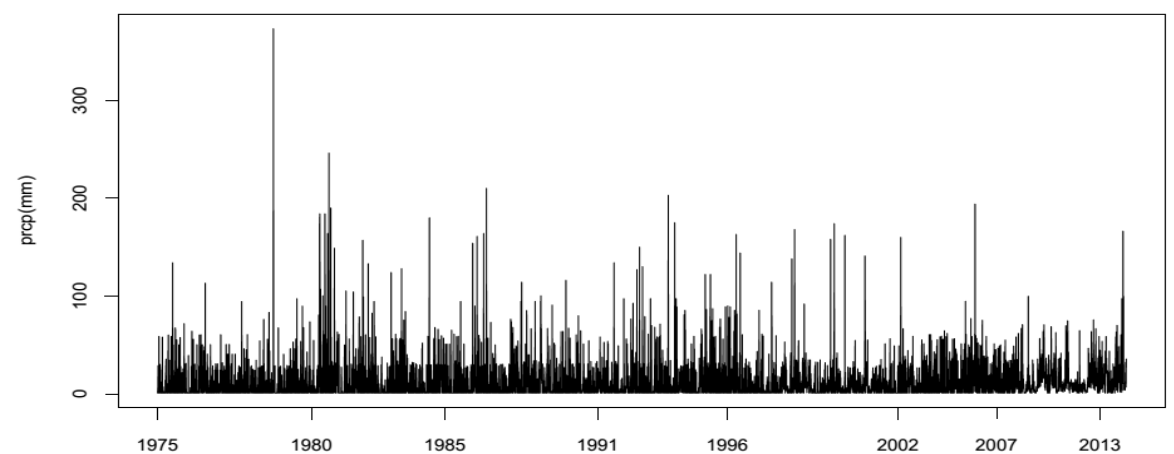

Figure 3c. The adjusted precipitation dataseries plot for Simpang Alai after the QM adjustment.

As for the RX1D and RX5D index trends, the results implied that all stations but Tabing experienced tendency of decreasing precipitation for these categories. For the RX1D index, the decrease trends were found in Simpang Alai and Ladang Padi while for the RX5D index, Ladang Padi, Batu Busuk, and Simpang Alai have shown the negative values. The significance test results for the RX1D index proved significant for Simpang Alai and Ladang Padi, whereas Simpang Alai, Batu Busuk and Ladang Padi are significant to the RX5D index. Besides the discussed indices, the precipitation extreme indices that can be directly utilized to indicate the declining amount of precipitation are CDD and CWD. The falling trend can be perceived with a positive CDD index and a negative CWD index. In Table 3, the majority of the stations have a positive CDD index, with Ladang Padi being the only exception. The highest positive CDD is calculated for Batu Busuk, demonstrating an increase of 0.32 day during the study period. As opposed to this trend, Ladang Padi sees a decrease of 0.27 day within the same period. 
Meanwhile, reversing results were obtained when it came to determine the CWD index. It is found that only Ladang Padi that has a positive value while the rest stations observed negatives. The largest reduction of the number of consecutive wet days was found in Batu Busuk, which is at a rate of 0.34 day while Ladang Padi experiences an increasing trend of consecutive rainy days by a slight addition of 0.07 day during the study period. In line with the PRCPTOT index, both the CDD index and the CWD index collectively indicated a decreasing precipitation trend in the Batang Kuranji Watershed and the Batang Air Dingin Watershed. The results from the significance test have observed that the CDD index is significant for all stations, excluding Gunung Nago. It means that the increasing trend of the number of consecutive dry days is apparent for the Batang Kuranji Watershed and the Batang Air Dingin Watershed, however the Batang Arau Watershed observes a decreasing trend of the number of consecutive wet days in the area.

Table 3. Significance trend of selected extreme precipitation indices for rain-gauge stations in the area of study

\begin{tabular}{|c|c|c|c|c|c|c|c|c|}
\hline \multirow{2}{*}{$\begin{array}{l}\text { Rain-gauge } \\
\text { locations }\end{array}$} & PRCPTOT & RX1D & RX5D & CDD & CWD & R0 & R50 & R100 \\
\hline & (mm/years) & $(\mathrm{mm})$ & $(\mathrm{mm})$ & (days) & (days) & (days) & (days) & (days) \\
\hline Simpang Alai & -47.215 & -2.233 & -2.451 & 0.198 & -0.068 & 1.497 & -0.347 & -0.123 \\
\hline Batu Busuk & $\begin{array}{l}-75.749 \\
\end{array}$ & -0.683 & -3.595 & 0.318 & -0.338 & 2.625 & -0.511 & -0.081 \\
\hline Gunung Nago & -29.557 & -0.120 & -1.022 & 0.187 & -0.230 & 2.644 & -0.171 & -0.072 \\
\hline Tabing & -5.911 & 0.922 & 0.469 & 0.223 & -0.020 & 0.362 & -0.095 & 0.014 \\
\hline Gunung Sarik & -40.63 & -0.463 & -1.365 & 0.187 & 0.108 & 0.581 & -0.324 & -0.137 \\
\hline Ladang Padi & 19.607 & -2.137 & -4.166 & -0.273 & 0.074 & -1.351 & -0.132 & -0.279 \\
\hline
\end{tabular}

Table 4. Significance test results of selected extreme precipitation indices for rain-gauge stations in the area of study

\begin{tabular}{|l|c|c|c|c|c|c|c|c|}
\hline $\begin{array}{c}\text { Rain-gauge } \\
\text { locations }\end{array}$ & PRCPTOT & RX1D & RX5D & CDD & CWD & R0 & R50 & R100 \\
\hline Simpang Alai & a & a & a & a & a & a & a & a \\
\hline Batu Busuk & a & b & a & a & a & a & a & b \\
\hline Gunung Nago & b & b & b & b & a & b & b & b \\
\hline Tabing & $\mathrm{b}$ & $\mathrm{b}$ & $\mathrm{b}$ & a & b & a & b & b \\
\hline Gunung Sarik & $\mathrm{b}$ & $\mathrm{b}$ & $\mathrm{b}$ & $\mathrm{a}$ & $\mathrm{b}$ & $\mathrm{a}$ & $\mathrm{a}$ & $\mathrm{b}$ \\
\hline Ladang Padi & $\mathrm{b}$ & $\mathrm{a}$ & $\mathrm{a}$ & $\mathrm{a}$ & $\mathrm{b}$ & $\mathrm{a}$ & $\mathrm{b}$ & $\mathrm{a}$ \\
\hline
\end{tabular}

$\mathrm{a}=$ significance test on the trends with a confident level of $5 \%$

$\mathrm{b}=$ not significance test

The R0 index, as shown in Table 3, denotes that all stations experience an increasing trend of the number of consecutive dry days marked by the negative values, with the exception being Ladang Padi. The highest R0 index is determined for Gunung Nago and Batu Busuk, at a rate of 2.64 days and 2.62 days, respectively. In contrast, a decreasing trend of 1.35 days during the study period is calculated for Ladang Padi. The significance test for the R0 index trend has been significant for all stations, except for Gunung Nago.

Furthermore, the R50 index and the R100 index, both are indicating heavier precipitation, are found to be negative in almost all the stations. Table 3 has summarized the R50 index and shows the highest decreasing trend is experienced by Batu Busuk (0.51 day), followed by Simpang Alai (0.35 day) and Gunung Sarik (0.32 day) during the observation period. The significance test for this index, as revealed in Table 4 , yields significant results for each station. Meanwhile for the R100 index, all the stations indicate a negative trend, except for Tabing. The combination of a negative R50 index and a positive R100 index suggests that Tabing undergoes an increase of heavy precipitation frequency while the moderate precipitation goes for a 
declining trend. The largest decreases are respectively found in Ladang Padi ( 0.28 day), Gunung Sarik (0.14 day) Simpang Alai (0.12 day). The significance test for this index is not as good as the previous index, as only the results for Simpang Alai and Ladang Padi that are significant. One of the consequences of the occurrence of moderate to extreme droughts as a result of the decline of precipitation is substantial difficulty to the demand of water for agriculture, clean water service, as well as land degradation in the watershed areas. This is due to the fact that the limited amount of water is quickly evaporated to the atmosphere and does not have the chance to infiltrate and be restored in the soil. On a different occasion, precipitation that comes following a long dry period is more often than not insufficient to replenish the water in the soil reservoir, which will be worsening the water debit condition in the watershed.

The results from the calculated extreme precipitation indices have described the decreasing trend of precipitation in the focused watersheds in and around Padang. Such a trend, in particular, is apparent to the Batang Kuranji Watershed, which is regarded as the largest and most influential watershed for Padang, that any significant changes will bring negative impacts to the city. Among the considered indices, PRCPTOT, R0 and R50 (illustrated in Figure 4a, 4b and 4c, respectively) emphasize the problem in this watershed: a declining trend in the annual total precipitation dataseries, an increasing tendency of the present of days without rainfall and a gradual loss of days with precipitation of at least $50 \mathrm{~mm}$.

As seen from Figure $4 \mathrm{a}$ and $4 \mathrm{~b}$, it seems that there is an opposing trend displayed by both indices in the trendlines. It can be exemplified from the data in 1997, when the total rainfall reached its minimum while the number of days without rain climbed to the peak. In the following year, however, a reverse situation took place as the amount of rainfall topped the plot while the number of days without rain bottomed the graph. These two interesting features came to an understanding as a result of a globally-occurring climate phenomenon known as El Nino/La Nina. In 1997, a very strong El Nino was prevalent in the Pacific and delivered its impact to the drying watersheds in Padang. Contrastingly in 1998, a strong La Nina occurred in the region and brought excessive amount of rainfall in the watersheds. Meanwhile in Figure 4c, although there is no straightforward explanation that implies the correlation between atmospheric circulations and the $\mathrm{R} 50$ index, the plot has suggested that there is an obvious decrease of the number days with precipitation above $50 \mathrm{~mm}$ in the Batang Kuranji watershed.



Figure 4a. Timeseries plot of PRCPTOT index in the Batang Kuranji Watershed for 1975-2013. 


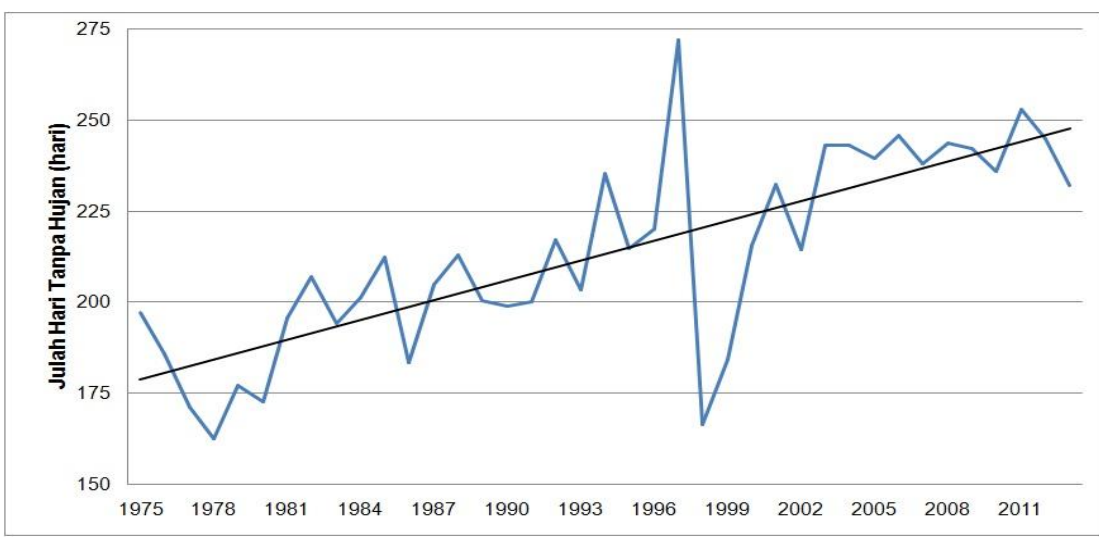

Figure 4b. Timeseries plot of R0 index in the Batang Kuranji Watershed for 1975-2013.

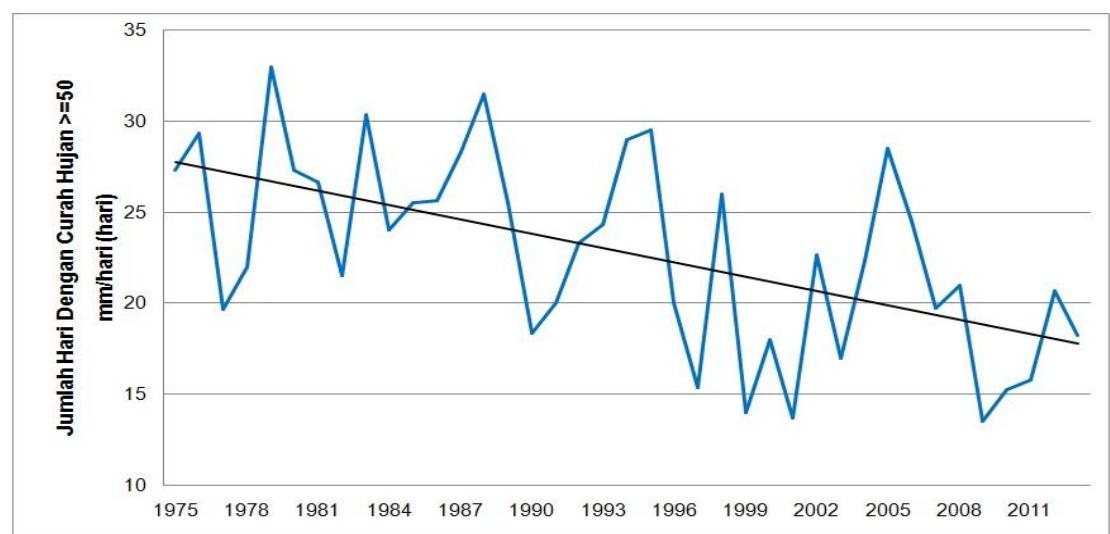

Figure 4c. Timeseries plot of R50 index in the Batang Kuranji Watershed for $1975-2013$

Extreme precipitation indices that occurred in the watersheds in and around Padang have pointed out that the trends are related to the variability of atmospheric circulation pattern not only on a localized area, but also on a wider scale (regional/global), from which the reason behind this is dealing with the ongoing global warming as a consequence of the increasing amount of greenhouse gases in the atmosphere. As such, one of the impacts of global warming is to influence the atmospheric circulations on a regional/global scale, in which one of the results in the decrease of precipitation in the watersheds in and around Padang. The affected atmospheric circulations are ENSO, IOD, ISO and the development of tropical cyclones. According to Nugroho (Nugroho, 2003; Nugroho, 2005), the declining trend of annual precipitation in this period was prevalent during the present of global atmospheric circulations; Dipole Mode Positive (DMI+) in 1994 and strong El Nino in 1997. These two phenomena are basically related to the sea surface temperatures in the maritime continent, particularly in the Indian Ocean, which in turns affect the precipitation in West Sumatra. Although it is inconclusive, it has been suggested that global warming will intensify the occurrence of strong El Nino. The impacts, however, may differ between one place and another, depends strongly on the local characteristics of the place. Another possible reason on the declining trend of precipitation particularly in the tropical areas is the expansion of the tropics as a result of the increasing global temperatures. Consequently, the warmer condition like in the tropics reaches more areas nearby the original location, or the number of rainy days in the tropics is diminishing as a result of the shared water vapour with the new emerging tropical region (Aldrian, 2007). 


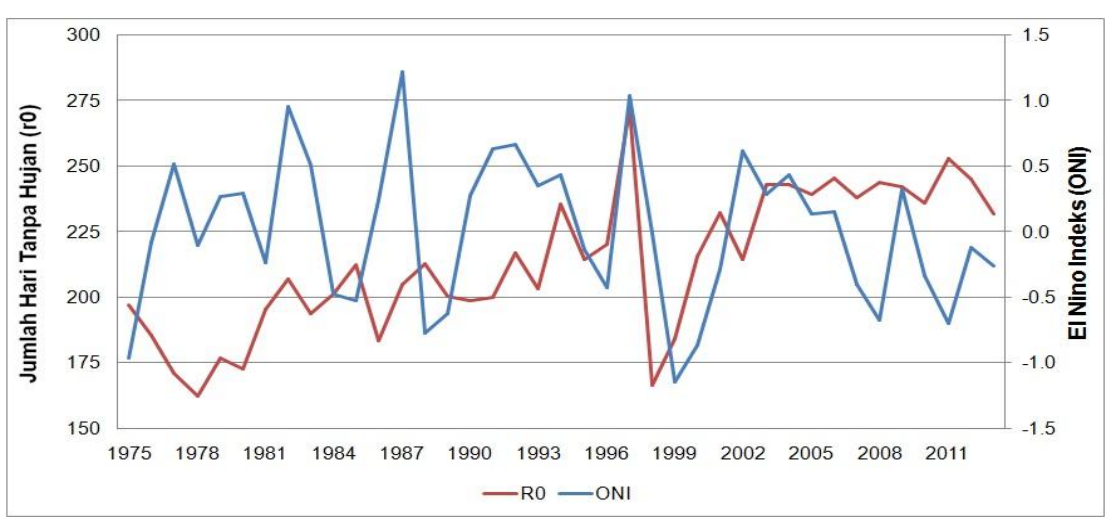

Figure 5a. The R0 index in the Batang Kuranji Watershed and Oceanic Nino Index (ONI)



Figure 5b. The R0 index in the Batang Kuranji Watershed and Dipole Mode Index (DMI).

Figure $5 \mathrm{a}$ and $5 \mathrm{~b}$ show the correlation between $\mathrm{R} 0$ and the two global atmospheric circulations, namely El Nino (ONI) and Dipole Mode Index (DMI). From the both figures, it is found that there are no apparent relationships either between R0 and ONI or between R0 and DMI, with the coefficient correlations of 0.77. However, if the relationships are taken on a case-by-case basis, especially during strong El Nino or positive DMI like in 1994, 1997 and 1998, the relationships become much clearer. It has been understood that besides El Nino, positive DMI also bring a drier condition over West Sumatra, particularly for Padang, and this condition will become more pronounce when the two events occur on the same time, as it happened in 1997.

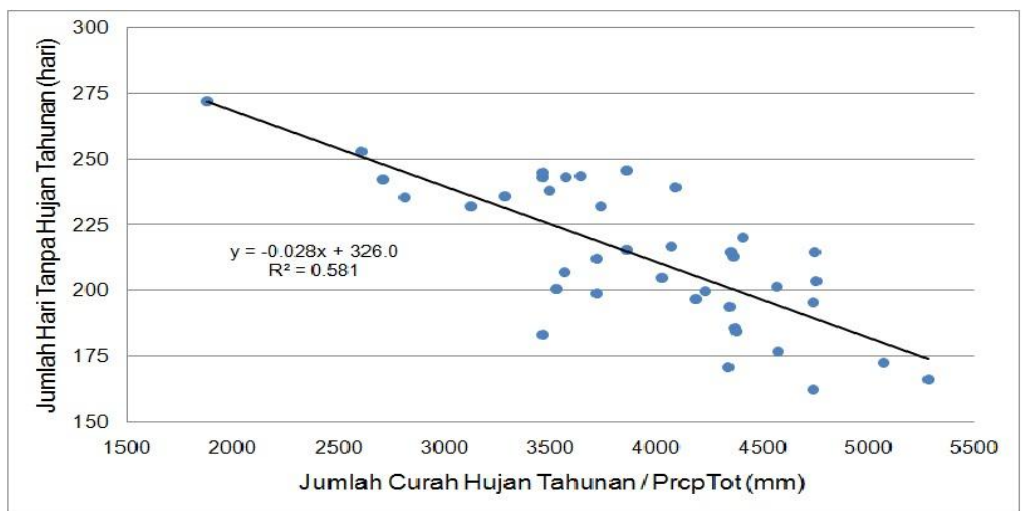

Figure 6a. Scatterplot between R0 and PRCPTOT in the Batang Kuranji Watershed. 
Figure $6 \mathrm{a}, 6 \mathrm{~b}$ and $6 \mathrm{c}$ show the correlation between the PRCPTOT index and other indices (R0, CDD and R50).As it is displayed in Figure 6a, the correlation coefficient ( $r$ ) between PRCPTOT and R0 in the Batang Kuranji Watershed is 0.76, whereas the $\mathrm{r}$ value between PRCPTOT and CDD in the same location is only 0.42 . It means that most of the annual precipitation amount reduction in this area is driven by the fact that there are more days without rain in a year. This feature is more effective in reducing the precipitation than the cumulative time without raining. Moreover, the correlation between PRCPTOT and R50 in the Batang Kuranji Watershed is positively correlated, with $\mathrm{r}$ of 0.53 . This correlation suggests that the more frequent the number of days with precipitation at least $50 \mathrm{~mm}$, the more the total amount of precipitation annually, and vice-versa. It is then suggested that less frequent days with moderate to heavy precipitation on a year-to-year basis will contribute to the declining trend of total annual precipitation. Therefore, it is important to further investigate the relationship among the extreme precipitation indices to better understand about the current precipitation trend, as well as to better predict the long-term precipitation trend in order to prepare adequate climate change adaptation and mitigation strategies.

\section{Conclusions}

The results from homogeneity test of the precipitation data show there are some rain-gauge stations in which the data are inhomogeneous, which is shown by the changepoint in the dataseries. As a result, the QM adjustment is performed for these dataseries in order to make them homogeneous. Furthermore, from the trend analysis of extreme precipitation indices, there is strong and significantly tested temporal variation on the data taken from the Batang Kuranji Watershed and the Batang Air Dingin Watershed, especially for the trend that shows the declining amount of precipitation, such as PRCPTOT, R0 and R50. Meanwhile, the relationship between extreme precipitation indices and global atmospheric circulations indicates a correlation between the two. It can be suggested from the correlation between R0 and strong El Nino or positive DMI, like in 1994 and 1997. The correlation between PRCPTOT and R0 can be further used to study different factors or extreme precipitation indices that affect the decline of precipitation for a long-term period, in order to encounter the challenges to formulate adaptation and mitigation strategies.

\section{Acknowledgements}

The author wishes to thank the Waterboard Council (Dinas Pengelolaan Sumber Daya Air/PSDA) of the West Sumatra Province who has kindly provided the data from their rain-gauge stations. Special thanks are also addressed to the BMKG-DIDAH Project team for the support by holding the training on Extreme Climate Index using the RClimDex program at the International Workshop on Data Rescue (DARE) on 7-11 December 2009 in Bogor, Indonesia.

\section{References}

Aldrian, E. (2007). Perubahan iklim global dan dampak terhadap iklim benua maritim di laut dan di daratan. (Indonesia: Prosiding Jurnal Club Tahun 2007. Badan Meteorologi dan Geofisika. ISBN:978-979-1241-11-3

Haylock, M., and Neville Nicholls. (2000). Trends in extreme rainfall indices for an update high quality data set for Australia, 1910-1998. Int. J. Climatol. 20:1533-1541.

Joshi, V.R. and M. Rajeevan. (2006). Trends in precipitation extremes over India NCC (India: Research Report, National Climate Centre, India Meteorological Departement). 
Klein Tang, A.M.G. (2006). Changes in daily temperature and precipitation extremes in central and south Asia. Journal of Geophys Research, 111, D16105, doi:10.1029/2005JD006316

Nugroho, S., Heron, T., Eddy, S. (2009). Trend Curah Hujan Ekstrim di Kota Padang. Megasains 4:25-38.

Nugroho, S 2003.Kaitan El Nino 1997 Terhadap Tingkat Kekeringan dan Musim di Sumatera Barat Jurnal Meteorologi dan Geofisika Vol. 4 No. 2.

Nugroho, S. (2005). Distribusi Curah Hujan di Sumatera Barat pada Saat Dipole Mode Even Positif Jurnal Meteorologi dan Geofisika Vol. 5 No. 3.

Sheikh, Muhammad, M., Ahmed, Ahsan, U., Kolli, R.K., Shresta, Madan, L., and Dharmarathna, G.H.P. (2005). Development and Application of Climate Extreme Indices and Indicator for Monitoring Trends in Climate Extremes and Their Socio-Economic Impacts in South Asian Countries (India: Final Report for APN Project 2005-10-NSY-Sheikh).

Putra, A. (2012). Studi Erosi Lahan Pada DAS Air Dingin Bagian Hulu di Kota Padang (Padang: Skripsi, Universitas Negeri Padang).

Roy, Shouraseni, S., and Balling, Roberth, C, Jr. (2004). Trend in extreme daily precipitation indices in India. Int. J. Climatol. 24:457-466 doi:10.1002/joc.995

Rupa Kumar, K., pant, G.B., Parthasarathy, b. And Sontakke, N. (1992). Spatial and subseasonal pattern of the long-term trends of India summer monsoon rainfall. Int. J. Climatol. 12:257-268.

Suppiah, R., and K. Hennessy. (1998). Trends in seasonal rainfall, heavy rain-days, and number of dry days in Australia 1910-1990. Int. J. Climatol.18: 1141-1155.

Timo, S., Anu, M., Pia, A., Tuija, R.A., and Toni, A. (2002). Detecting Trends of Annual Vallues of Atmospheric Pollutans by The Mann-Kendall Test and Sesn's Slope Estimates-The Excel Template Application Makesens (Finnish: Meteorological Institute, Helsinki)

Xiaolan L. Wang and Yang Feng. (2013). RHtests_dlyPrcp User Manual. (Canada: Climate Research Division Atmospheric Science and Technology Directorate Science and Technology Branch, Environment Canada Toronto, Ontario)

Zhang, X. (2005). Trends in Middle East climate extreme indices from 1950 to 2003 Journal of Geophys Research, 110, D22104, doi:10.1029/2005JD006181.

Zhai, P., Anjian Sun, Fumin Ren, Xiaonin Liu, Bo Gao and Qiang Zhang. (1999). Changes of climate extremes. Climatic Changes 42:203-218 doi:10.1023/A:1005428602279.

Zhang, X., and Feng Yang. (2004). RClimDex User Manual. (Canada: Climate Research Branch, Environment Canada, Downsview, Ontario). 